\title{
Taking Federalism Seriously: Limiting State Acceptance of National Grants
}

Federalism was one of the central structural principles guiding the Framers of the Constitution, and it remains central to our interpretation of that document today. ${ }^{1}$ Because Federalism is a system of allocating power between the state and national governments, its vitality depends on the policing of their respective spheres of authority. A number of explicit safeguards in the Constitution prevent the states from encroaching upon the authority of the national government. ${ }^{2}$ The Supreme Court, however, has permitted erosion of corresponding safeguards of state authority. The Court has removed virtually all internal limits $^{3}$ on national power by abandoning the practice of strictly construing the powers delegated to the national government. In an effort to preserve Federalism, the Court, in National League of Cities v. Usery, ${ }^{4}$ developed a set of external limits on national power. That decision, however, applies only to direct regulation of the states. While direct regulation is limited, indirect regulation, carried out through conditions placed upon national grants to the states, has increasingly served as a vehicle for national control of the states. ${ }^{5}$

1. Younger v. Harris, 401 U.S. 37, 44-45 (1971). For a discussion of the differences between the Framers' definition of Federalism and the modern definition, see Diamond, What the Framers Meant

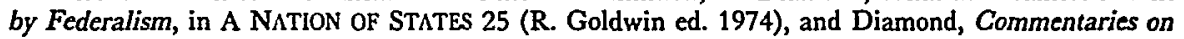
The Federalist: The Federalist on Federalism: "Neither a National Nor a Federal Constitution, But a Composition of Both," 86 YALE L.J. 1273 (1977). The distinction is a semantic one, for the Framers considered a "federal" government to be a mere confederation of sovereign states and a "national" government to be a unitary government. They believed they had created a "composition of both." THE FEDERALIST NO. 39 at 250 (J. Madison) (E. Earle ed. 1937). That "composition" has come to be known as Federalism. Diamond, What the Framers Meant By Federalism, supra, at 27-28.

2. The most crucial of these is the supremacy clause:

This Constitution, and the Laws of the United States which shall be made in pursuance thereof; and all Treaties made, or which shall be made, under the Authority of the United States, shall be the supreme Law of the Land; and the Judges in every State shall be bound thereby; any Thing in the Constitution or Laws of any State to the Contrary notwithstanding. U.S. CONST. art. VI, cl. 2.

3. Internal limits on power operate by limiting the extent of the delegated power. External limits operate by creating zones into which the power may not reach. Thus, construing a grant of power narrowly is a method of limiting power internally, while the promulgation of a Bill of Rights is a method of limiting power externally.

4. 426 U.S. 833 (1976).

5. See pp. 1695-97 infra.

The Reagan administration has proposed replacing many grants that carry extensive conditions with unconditional "block" grants. 39 CONG. Q. WEEKLY REP. 708, 708-10 (1981). While the administration's public opposition to extensive conditions on grants to states may prevent new programs from being approved, it is unlikely to lead to a real reduction in the use of conditions to achieve national policy goals. The administration has proposed conditions of its own, see, e.g., id. at 450 (proposed "workfare" requirement for Aid to Families with Dependant Children), and it is quite possible that conditions of one sort will simply be replaced by conditions of another. In July of 1981, most of the administration's block grant proposals were defeated in spite of its overall budget success. 


\section{Conditional Grants}

This Note argues that the doctrine currently controlling conditional grants is incapable of preserving the legitimate interests of the states. Current internal and external limits on national power provide no check on the conditions placed upon those grants, enabling the national government to invade almost any area of state power at will. In order to limit national infringement of legitimate state interests, the Note proposes a doctrine establishing a zone of power belonging exclusively to the states and a constitutional requirement that the states make all policy decisions on matters within this zone free from the influence of the national government. The Note argues that because national use of conditional grants to influence state policy often impinges on exclusive state powers, a state's acceptance of such grant conditions constitutes a failure to make such an uninfluenced decision. The Note concludes that state acceptance of such conditions is therefore unconstitutional, and provides examples of conditions it would be unconstitutional for a state to accept.

\section{Conditional Funding}

Currently, the most popular vehicle for national regulation of state policies is the conditional grant to state governments. ${ }^{6}$ Such grants pose a serious threat to the continuing vitality of Federalism, yet current doctrine is incapable of dealing with the problem.

\section{A. The Conditional Grant System}

National grants to state governments now constitute approximately onequarter of total state and local budgets, ${ }^{7}$ and the conditions that are attached to those grants reach far into areas traditionally within the scope of state power. ${ }^{8}$ National conditions, for example, have required that states

See id. at 1390. Even if the administration is eventually successful in ending conditional grants, it is doubtful that the victory will stand the test of time. Representatives and Senators as well as Presidents are unlikely over the long run to pay the bill for state-run programs without taking an active role in the planning and administration of those programs.

6. This is so because direct regulation has been severely limited. See National League of Cities v. Usery, 426 U.S. 833 (1976) (unconstitutional to apply minimum wage to states); District of Columbia v. Train, 521 F.2d 971, 990-95 (D.C. Cir. 1975), vacated and remanded per curiam sub nom. EPA v. Brown, 431 U.S. 99 (1977) (unconstitutional to require states to adopt provisions of national environmental program). But see Pennsylvania v. EPA, 500 F.2d 246 (3rd Cir. 1974) (constitutional to require states to adopt provisions of national enviromental regulatory program). If direct regulations that invade state prerogatives were not unconstitutional, the states would hold those powers at the sufferance of the national government, and Federalism would be a dead letter.

7. U.S. ADVISORY COMM'N ON INTERGOVERNMENTAL RELATIONS, AN AGENDA FOR AMERICAN FEDERALISM: RESTORING CONFIDENCE AND CONPETENCE 3 (1981) (series title: "The Federal Role in the Federal System: The Dynamics of Growth").

8. See U.S. ADVISORY COMM'N ON INTERGOVERNMENTAL RELATIONS, SUMMARY AND CONCLUDING OBSERVATIONS 66 (1978) (series title: "The Intergovernmental Grant System: An Assessment and Proposed Policies"); pp. 1715-16 infra. 
adopt nationally approved regional sewage treatment plans, ${ }^{9}$ nationally designed programs for regulating health industries, ${ }^{10}$ and nationally authorized plans to limit air pollution. ${ }^{11}$ Conditions such as these promote policies closely related to the goals of the national grant. An increasing number of conditions, however, impose requirements unrelated to the goals of the grants to which they are attached. ${ }^{12}$ These conditions reach such matters as state political procedures, ${ }^{13}$ hiring practices, ${ }^{14}$ and procurement policies. ${ }^{15}$

The Framers of the Constitution could not have contemplated that the national government would use conditional grants to influence the states' exercise of their powers to the extent that is now possible, for in their time even the most expansive interpretations of the spending power ${ }^{16}$ held it to be limited by the words "general welfare" to matters of national, not local, concern. ${ }^{17}$ Indeed, until the New Deal, national grants to the states were quite limited, ${ }^{18}$ and imposed few conditions. ${ }^{19}$ It was not until the 1960 s that the overall tenor of national grants shifted from assisting the states in achieving their own goals to using the states as instruments to achieve national goals..$^{20}$ State dependence on national funding grew as states attempting to raise their own funds for social programs found it impossible to raise taxes without risking damage to their economies and emigration of middle class taxpayers. ${ }^{21}$

9. 33 U.S.C.A. $§ 1288$ (West 1978 \& Supp. 1981).

10. 42 U.S.C.A. $\$ \S 300 \mathrm{~m}$ to $300 \mathrm{~m}-2$ (West Supp. 1981).

11. 42 U.S.C. $\$ \S 7501-7508$ (Supp. III 1979).

12. U.S. ADVISORY COMM'N ON INTERgOVERNMENTAL RELATIONS, GategORICAL GRANTS: THEIR ROLE AND DESIGN 234 (1978) (series title: "The Intergovernmental Grant System: An Assessment and Proposed Policies") [hereinafter cited as ACIR REPORT].

13. Id. at 259.

14. The Davis-Bacon Act requires that an employer pay "prevailing wages." 40 U.S.C. $\$ \S 276 a$ to $276 \mathrm{a}-5$ (1976). Its provisions have been made applicable to some state programs through conditions on national grants. ACIR REPORT, supra note 12, at 255; see, e.g., 49 U.S.C. $\$ 1609$ (a) (1976) (mass transit programs). The Urban Mass Transit Act requires that states provide special protections and privileges to transit workers. Id. $\S 1609$ (c).

15. The Federal Procurement Policy Act of 1974, as amended, provides for the conditioning of national grants on state adoption of nationally designed procurement policies. 41 U.S.C. $\$ 405$ (1976 \& Supp. III 1979). The Office of Management and Budget has adopted procurement guidelines applicable to the states in their use of national grants. See OMB Circular No. A-102, Attachment O (1981) (on file with Yale Law Journal).

16. "The Congress shall have Power . . . to pay the Debts and provide for the common Defence and general Welfare of the United States ...." U.S. CONST. art. I, § 8, cl. 1.

17. See United States v. Butler, 297 U.S. 1, 65-67 (1936) (discussing Framers' intent).

18. See W. GRAVES, AMERICAN INTERGovernmental Relıtions 477-526 (1964). Prior to the 1930s, national grants went mainly for road and canal building, agricultural education and research, and colleges. Id. In 1915 national cash grants totaled only $\$ 5$ million; between World War I and the New Deal they amounted to only $\$ 100$ million annually. M. REAGAN \& J. SANzONE, THE NEW FEDERALISM 55 (2d ed. 1981).

19. See M. REAGAN \& J. SANZONE, supra note 18, at 56 ("substantial federal supervision" began in 1930s).

20. J. SUNDQUIST, MAKING FEDERALISM WORK 1-3 (1969).

21. See Rockefeller, Revenue Sharing-A View From the Statehouse, 60 Geo. L.J. 45, 48-51 


\section{Conditional Grants}

As their dependence on national funds has grown, states have seen the conditions under which they receive those funds become increasingly restrictive. ${ }^{22}$ Thus the doctrine controlling the national government's power to set conditions has taken on new importance.

\section{B. Present Limits On Conditional Grants}

Present doctrine purports to determine the constitutionality of conditions on national grants on a case-by-case basis, by examining whether the recipient state is being coerced. Although the leading case on the question, Steward Machine Co. v. Davis, ${ }^{23}$ provides no clear standard, ${ }^{24}$ the most persuasive interpretation of the case is that it adopts a two-tiered test. ${ }^{25}$ First, the expenditure and the condition attached to it must be "reasonably related to a legitimately national end," and second, the state must be induced, not coerced, into accepting the condition. ${ }^{26}$

The first tier of the test is enfeebled by the absence of internal limits on congressional power to spend. ${ }^{27}$ The test is thus limited to the question whether the condition itself is reasonably related to a legitimate national end. The condition need not, however, be justified in its own right. It need only be justified as a part of the overall expenditure program, because any condition relating to the purpose of the program is in the general welfare if the program is in the general welfare. No matter how much a condition intrudes into an area of state power, it passes the first tier if it is related to the expenditure program. ${ }^{28}$ Because Congress may spend for any purpose

(1971).

22. See J. SUNDQUIST, supra note 20, at 1-6; Madden, Future Directions for Federal Assistance Programs: Lessons from Block Grants and Revenue Sharing, 36 FED. B.J. 107, 107-20 (1977). The Reagan administration probably will not be able to turn the tide. See note 5 supra.

23. 301 U.S. 548 (1937).

24. Justice Cardozo's decision initially suggested that to be unconstitutional, conditions must be shown to be "weapons of coercion, destroying or impairing the autonomy of the states." Id. at 586. Later in the opinion, however, he suggested that a stricter standard might be applied, by reserving the question whether conditions could be unrelated to matters the national government is empowered to regulate. Id. at 590. Finally, in distinguishing United States v. Butler, 297 U.S. 1 (1936), which seemed clear authority that the conditions involved in Steward violated the Constitution, Cardozo stressed that these conditions had been approved by the state, were revocable by it, and were related to matters on which the national and state governments could lawfully cooperate. 301 U.S. at 592-93.

25. Vermont v. Brinegar, 379 F. Supp. 606, 616 (D. Vt. 1974). While Brinegar has not been widely cited, it states concisely and clearly the approach that most courts follow.

26. Id.

27. Congress may expend money for the general welfare of the United States. United States v. Butler, 297 U.S. 1, 66 (1936); U.S. CONST. art. I, § 8, cl. 1. Congress has wide power to determine what is in the general welfare, and is constrained only by limits found elsewhere in the Constitution. Buckley v. Valeo, 424 U.S. 1, 90-91 (1976) (per curiam).

28. See, e.g., Oklahoma v. United States Civil Serv. Comm'n, 330 U.S. 127, 142-44 (1947) (upholding requirement that state official not participate in partisan politics); Florida v. Mathews, 526 F.2d 319, 325-26 (5th Cir. 1976) (upholding condition regulating occupations of members of state licensing board); Arizona State Dep't of Pub. Welfare v. HEW, 449 F.2d 456, 473-74, 479 (9th Cir. 1971), cert. denied, 405 U.S. 919 (1972) (upholding condition requiring state to form advisory com- 
that does not violate the Constitution, no condition would violate this test provided that it is attached to the appropriate expenditure program. ${ }^{29}$ The first tier of the test thus provides no check on national incursions into areas of state power.

The second tier requires inducement, rather than coercion, of state action. If the courts were actually to put this tier of the test into effect, they presumably would often have to reach a conclusion about the mental state of legislators at the time they accepted a condition in order to determine whether the acceptance was made under "duress." To perform such group psychological analysis is exceedingly difficult, and there is no reason to believe that judges have any special expertise at the task. ${ }^{30}$

The inherent difficulties of the coercion test have led the courts, whenever they have reviewed conditions attached to grants, to find state acceptance of the conditions to be voluntary. ${ }^{31}$ This result is unsurprising given the implausibility of the idea of reading the legislative mind. Because a state is, in a formal sense, free to take or reject national money, and because coercion is practically unverifiable, the courts have resorted to the fiction of concluding that the state must be acting "voluntarily" when it accepts money and the conditions attached to it. ${ }^{32}$ Thus, the second tier of

mittees for its welfare program); Florida Dep't of Health \& Rehabilitative Serv. v. Califano, 449 F. Supp. 274, 283-85 (N.D. Fla.), aff'd per curiam on opinion of court below, 585 F.2d 150 (5th Cir. 1978), cert. denied, 441 U.S. 931 (1979) (upholding condition imposing extensive organizational requirements on state agency administering program).

29. The condition need not be directly related to the expenditure. Congress conditions the receipt of over $\mathbf{4 0}$ separate health care programs on a state's adoption of a particular cost control program for health care. 42 U.S.C.A. $\$ 300 \mathrm{~m}$ (West Supp. 1981). The conditions were upheld in their original form in North Carolina ex rel. Morrow v. Califano, 445 F. Supp. 532 (E.D.N.C. 1977), affd mem., 435 U.S. 962 (1978). One commentator, however, has called for a stricter test of the relation between the condition and the objective. See Kaden, Politics, Money, and State Soverejgnty: The Judicial Role, 79 COLUM. L. REV. 847, 896-97 (1979).

30. Courts do examine motive in equal protection analysis. See Washington v. Duvis, 426 U.S. $229,239-42$ (1976). Conditional grant cases, however, pose a special difficulty. In these cases the legislators themselves may not know whether they have been "coerced," for they may never have decided independently whether they would want to embrace the policy that the national condition requires that they adopt. Furthermore, even when it is clear that the legislators oppose a condition, it is unclear what would constitute coercion. In the equal protection context, either a conscious choice is involved, or the absence of a conscious choice is dispositive. See id. at 242 ("invidious discriminatory purpose" required). Yet in spite of this comparatively clear standard, court determinations of school board motive in segregation cases have proven questionable and inconsistent. See Note, Reading the Mind of the School Board: Segregative Intent and the De Facto/De Jure Distinction, 86 YALE L.J. 317, 322-26 (1976).

31. Kaden, supra note 29 , at 893 .

32. There have been numerous cases in which courts have reasoned that state action is voluntary because the state may accept or reject the national grant. E.g., Oklahoma v. United States Civil Serv. Comm'n, 330 U.S. 127, 143-44 (1947); Walker Field, Colo., Pub. Airport Auth. v. Adams, 606 F.2d 290, 297-98 (10th Cir. 1979); Florida v. Mathews, 526 F.2d 3119, 325-26 (5th Cir. 1976); Oklahoma v. Harris, 480 F. Supp. 581,588 (D.D.C. 1979); Florida Dep't of Health \& Rehabilitative Serv. v. Califano, 449 F. Supp. 274, 284 (N.D. Fla.), aff'd per curiam on opinion of court below, 585 F.2d 150 (5th Cir. 1978), cert. denied, 431 U.S. 931 (1979); Montgomery County v. Califano, 449 F. Supp. 1230, 1247 (D. Md. 1978), af'd, 599 F.2d 1048 (4th Cir. 1979); North Carolina ex rel Morrow v. Califano, 445 F. Supp. 532, 536 (E.D.N.C. 1977), affd mem., 435 U.S. 962 (1978); Goodin v. 


\section{Conditional Grants}

the Steward Machine test has no bite. ${ }^{33}$

As a result of the failure of coercion analysis, the national government can effectively force almost any policy on the states by manipulating the amount of money the states receive. There is clear evidence that states adopt policies they would not otherwise adopt-policies opposed by a majority of their citizens-if the payoff in national money is big enough. ${ }^{34}$ Although the state's citizens may favor the particular bargain, the state's acceptance of a condition it would not otherwise accept suggests that the present system of controlling conditional grants endangers the Federalist allocation of powers.

\section{The Role of the States in the Federal System}

The values of Federalism remain central to our system of government. In order to protect those values it is necessary to define a zone of exclusive state powers that will be protected from the incursions of the national government.

\section{A. The Relevance of Federalism}

The goals that a Federalist system of allocating power furthers are numerous and interrelated. First, liberty is safest when governmental power is divided vertically as well as horizontally. ${ }^{35}$ The more centers of power in a nation, the more difficult it is for any individual or faction to control

Oklahoma, 436 F. Supp. 583, 586 (W.D. Okla. 1977).

33. Some commentators have suggested that National League of Cities v. Usery, 426 U.S. 833 (1976), signals new limits on conditional grants, apparently on the theory that if Congress may not invade the realm of essental state functions directly, it may not do so indirectly either. Stewart, Pyramids of Sacrifice? Problems of Federalism in Mandating State Implementation of National Environmental Policy, 86 YALE L.J. 1196, 1261-62 (1977) (suggesting that conditions must be closely related to state activity receiving national funds); Comment, Toward New Safeguards on Conditional Spending: Implications of National League of Cities v. Usery, 26 AM. U.L. REV. 726, 744-46 (1977). National League of Cities, however, which addressed direct and mandatory regulation of states, poses no challenge to the traditional analysis of conditional funding, which focuses on whether state acceptance of the condition is voluntary. Furthermore, National League of Cities explicitly states that the decision does not reach the issue of conditional grants. 426 U.S. at 852 n.17. The "coercion analysis with bite" suggested by these commentators cannot be derived from National League of Cities.

The cases on conditional grants to states since National League of Cities have continued to use the analysis of Steward Machine Co. See note 32 supra (citing cases); cf. Fullilove v. Klutznick, 448 U.S. $448,473-75$ (1980) (plurality opinion) (Burger, C.J.) (approving "the use of [conditional grants] to induce governments and private parties to cooperate voluntarily with federal policy"). At least one commentator has concluded that National League of Cities will not limit conditional grants. Comment, Federal Interference with Checks and Balances in State Government: A Constitutional Limit on the Spending Power, 128 U. PA. L. REV. 402,417 (1979).

34. For example, Wyoming recently decided not to confront the national government over the uniform national speed limit, in spite of widespread citizen opposition to the limit, because of a fear that it would lose national highway funds. Christian Science Monitor, Feb. 14, 1979, at 2, col. 1.

35. Federalism divides power vertically, between the national and state governments. Separation of powers divides power horizontally, among the executive, legislative, and judicial branches. 
that nation for the purpose of repression..$^{36}$ Second, the closer a unit of government is to the people it serves, the more likely it will be to implement policy goals they desire. ${ }^{37}$ Third, smaller organizations-and hence governmental units-because they are more easily controlled and managed, tend to be less bureaucratic and more efficient. ${ }^{38}$ Smaller organizations are more likely to experiment with new approaches to problems and thus discover more effective ways of achieving policy goals. ${ }^{39}$ Fourth, the vertical division of governmental power provides regionalism and other factionalisms with a healthy outlet, helping to prevent the rise of separatist movements. Although there are limits to the amount of diversity allowed by the Constitution, ${ }^{40}$ the adoption of a Federal system, with its opportunities for diversity, provides a vehicle for letting off steam, and thus helps to maintain the legitimacy of the national government. ${ }^{41} \mathrm{Fi}$ nally, in helping to preserve cultural and other kinds of diversity, Federalism checks the tendency of centralization to impose a boring sameness upon the nation. ${ }^{42}$

The Constitution enumerates the powers of the various branches of the national government and the rights of the American people. Its failure similarly to enumerate explicitly the powers of the states should not be taken as an implicit derogation of those powers. The Tenth Amendment reminds us that those powers not delegated to the national government belong to the states, ${ }^{43}$ and the document as a whole presumes a significant

36. THE FEDERALIST No. 10 (J. Madison) (E. Earle ed. 1937). 54.

37. See R. DAHL \& E. TUFTE, SIZE AND DEMOCRACY 65 (1973); Kaden, supra note 29, at 853 -

38. See Elazar, Cursed by Bigness or Toward a Post-Technocratic Federalism, PuBLIUS, Fall 1973, at 239, 280-81; Goodwin, The Shape of American Politics, COMMMENTARY, June 1967, at 25, 36-37; Wildavsky, A Bias Toward Federalism: Confronting the Conventional Wisdom on the Delivery of Governmental Services, PUBLIUs, Spring 1976, at 95, 118-19. Recent research into the consolidation of local services, such as police departments and schools, shows that smaller scale operations tend to provide better services and cost less than larger scale ones. See Ostrom, Size and Performance In a Federal System, Publus, Spring 1976, at 33, 72-73; Rogers \& Lipsey, Metropolitan Reforms: Citizen Evaluations of Performances in Nashville-Davidson County, Tennessee, Publius, Fall 1974, at $19,32-33$.

39. See I. SHARKANSKY, THE MALIGNED STATES 14 (2d ed.1978). If there is significant meaning to Mr. Justice Brandeis' famous model of states as "laboratories" for experimentation, New State Ice Co. v. Liebmann, 285 U.S. 262, 310-11 (1932) (Brandeis, J., dissenting), it must be that small organizations are more likely to experiment than big ones, for the national government would be free to set up model, localized experiments even without states. The equal protection clause might, however, prevent it from engaging in some experiments such as using different penalties for the same crime.

40. For example, the Constitution prohibits states from granting titles of nobility. U.S. CONST. art. $1, \S 10$, cl. 1 .

41. See R. DAHL, PluRalist Democracy in the United States 173 (1967); M. DaNielsoN, A HERSHEY, \& J. BAYNE, ONE NATION, SO MANY GOVERNMENTS 8-9 (1977).

42. See 1 A. DE TocQueville, Democracy IN AMERICA 91-92 (P. Bradley ed. 1945).

43. "The powers not delegated to the United States by the Constitution, nor prohibited by it to the States, are reserved to the States respectively, or to the people." U.S. CONST. amend. X. In United States v. Darby, 312 U.S. 100 (1941), the Court characterized the Tenth Amendment as nothing more than a truism, creating no independent limit on national power. Id. at 124. By holding that even when 


\section{Conditional Grants}

role for them." The states are given a general police power, which overlaps with the powers of the national government. ${ }^{45}$ But they are also given a set of exclusive powers, allocated to them either by explicit language of the Constitution, or by implicit reservation, as determined by the courts. ${ }^{46}$

\section{B. The States' Exclusive Powers}

Although exclusive state powers could once be identified by looking to those powers not explicitly delegated to the national government by the Constitution, the lesson of the post-1937 decisions on national power ${ }^{47}$ is that this understanding of Federalism is no longer acceptable. There simply are no meaningful internal limits to national power. ${ }^{48}$ The post-1937 cases do not imply that the realm of exclusive state powers is an empty set; they merely shift the focus of analysis. Instead of determining whether the power is among those delegated to the national government, two inquiries become necessary. First, the courts must examine whether the particular use of the power invades an area delegated exclusively to the states; that is, whether it violates an external limit on the power of the national government. Second, the courts must examine whether, in accepting the national condition, the state has allowed the national government to influence its exercise of a power delegated exclusively to the states. Federalism analysis must, therefore, shift from examining the limits of national power to searching for those areas of state power that may not be invaded or voluntarily relinquished.

There are three types of exclusive state powers: control over internal

Congress has plenary power over a matter it may not exercise that power in a way that impairs certain attributes of state "sovereignty," National League of Cities v. Usery, 426 U.S. 833, 845 (1976), the Court has implicitly rejected the Darby analysis. See 426 U.S. at 842-43.

44. Texas v. White, 74 U.S. (7 Wall.) 700,725 (1869) ("[T]he preservation of the States, and the maintenance of their governments, are as much within the design and care of the Constitution as the preservation of the Union and the maintenance of the National government. The Constitution, in all its provisions, looks to an indestructible Union, composed of indestructible States.")

45. Ziffrin, Inc. v. Reeves, 308 U.S. 132, 139-41 (1939).

46. See pp. 1702-09 infra.

47. See Wickard v. Filburn, 317 U.S. 111 (1942); United States v. Darby, 312 U.S. 100 (1941); Steward Mach. Co. v. Davis, 301 U.S. 548 (1937); NLRB v. Jones \& Laughlin Steel Corp., 301 U.S. 1 (1937).

48. Diamond, The Forgotten Doctrine of Enumerated Powers, PUBLIUS, Fall 1976, at 187, 187; see Stern, The Commerce Clause Revisited-The Federalization of Intrastate Crime, 15 ARIZ. L. REV. 271, 284-85 (1973). Martin Diamond believed that internal limits should be resurrected in order to preserve Federalism. Justice Rehnquist recently argued that such limits do exist under present law. Hodel v. Virginia Surface Mining \& Reclamation Ass'n, I0I S.Ct. 2352, 2389-92 (1981) (Rehnquist, J., concurring). There are, however, no recent cases enforcing internal limits on the power of the national government. The Court seems to have rejected that approach in favor of one protecting certain realms of exclusive state powers. In National League of Cities v. Usery, 426 U.S. 833 (1976), it held unconstitutional the application of minimum wage laws to the states, not on the basis of an internal limit on the commerce clause, id. at 841 , but on the ground that the exercise of that power invaded a protected attribute of state "sovereignty." Id. at 845 . 
governmental structure, control over certain areas of substantive social policy, and control over part of the process of changing the Federal system. What follows is a tentative attempt to identify and describe those powers. ${ }^{49}$

Type I: Control Over Internal Governmental Structure. A state has the power to establish and structure its government, allocating power as it wishes. ${ }^{50}$ It is for a state to decide, for example, whether it wishes to adopt a principle such as separation of powers. The only limitations on this power are those contained in the Constitution itself. ${ }^{51}$

Decisions such as whether to have a bicameral or unicameral legislature,$^{52}$ what executive offices should be created and how their occupants should be chosen, how long state officials' terms of office should be, whether to have an elective or appointive judiciary, how power should be allocated within the state government, what political subdivisions should be created, and what the powers of those subdivisions should be are all decisions allocating power within a state, and should therefore be considered Type I exclusive state powers. The power to decide such matters as where the state capital should be located, ${ }^{53}$ how much state and local employees performing traditional governmental functions should be paid, ${ }^{54}$ and what rules should govern that traditional type of state employment ${ }^{5 s}$

49. Professor Stewart suggests two types of state power deserving of constitutional protection, Stewart, supra note 33, at 1231-32, corresponding closely with what this Note labels Types I and II power, see pp. 1702-08 infra. His failure to mention Type III power, see pp. 1708-09 infra, is probably an oversight brought about by its limited relevance to the subject he is discussing-the Federalism problems relevant to national environmental policy. Stewart does not, however, describe his two types of powers as exclusive state powers, and, by including within his second category all services that states provide, he includes powers that the states do not hold exclusively. See Stewart, supra note 33 , at 1232 .

This Note does not seek to provide a complete listing of exclusive state powers; it seeks only to demonstrate that such a realm exists. The area of Type II power is intentionally left incomplete, because the Court has yet to make clear the extent of that power. States may possess other related types of exclusive powers as well. See, e.g., Oregon v. Mitchell, 400 U.S. 112, 152-219 (1970) (Harlan, J., dissenting in part) (states have broad powers to set qualifications for voting in national elections); id. at 293-96 (Stewart, J., dissenting in part) (same).

50. See Mayor of Philadelphia v. Educational Equality League, 415 U.S. 605, 615 n.13 (1974); Sweezy v. New Hampshire, 354 U.S. 234, 256 (1957) (Frankfurter, J., concurring in result); Highland Farms Dairy, Inc. v. Agnew, 300 U.S. 608, 612 (1937); Dreyer v. Illinois, 187 U.S. 71, 84 (1902).

51. See Oregon v. Mitchell, 400 U.S. 112, 124 (1970) (separate opinion) (Black, J.). Mitchell invalidated an attempt by Congress to determine the qualifying age for voting in state elections, a clear intrusion into Type I power. The passage of the Twenty-sixth Amendment, which established the 18-year-old vote, followed. The most notable constitutional limit on the exercise of this power is the so-called "one man-one vote" rule for apportioning state legislatures, see Reynolds v. Sims, 377 U.S. 533 (1964), and for electing state officers, see Gray v. Sanders, 372 U.S. 368 (1963). Congress has the power to enforce Fourteenth and Fifteenth Amendment limits. U.S. CoNST. amend. XIV, § 5; id. amend. XV, \& 2; see pp. 1710-11 infra.

52. See Stewart, supra note 33 , at 1231.

53. See Coyle v. Oklahoma, 221 U.S. 559 (1911).

54. National League of Cities v. Usery, 426 U.S. 833 (1976).

55. Id. 


\section{Conditional Grants}

is also exclusively the states'.

Type I power is of great significance because without control over their governmental processes, states would become nothing more than administrative arms of the national government, ceasing to exist as independent realms of power. ${ }^{56}$ Such a result would make a nullity of Federalism. An entity that does not possess Type I power cannot possess any other type of power exclusively, because its creator can always force it to carry out a desired policy by threatening to alter or destroy it. Moreover, from a view of politics that considers questions of governmental process to be as important to liberty as questions of substance, ${ }^{57}$ Type I power is important for its own sake, for decisions concerning it raise significant social policy questions.

Type II: Control Over Certain Areas of Substantive Social Policy. States also possess exclusive power over a number of areas of substantive social policy. If states were to have complete control over their governmental structure, but have supreme authority over no matters of substantive social policy, the former power would be meaningless. It is senseless to speak of the "separate and independent existence"s8 of states if that existence has no substantive purpose. The argument that although states may not be destroyed, they have no substantive power Congress cannot preempt, leaves them nothing more than vestigial organs.

In Hodel v. Virginia Surface Mining \& Reclamation Ass'n $n^{59}$ the Supreme Court interpreted its decision in National League of Cities v. $U s e r y^{60}$ in a manner that could effectively rob the states of exclusive power over any substantive matters. The Court reasoned that for an otherwise valid exercise of the commerce clause to fall under National League of Cities, it must regulate the states as states, address matters that are attributes of sovereignty (what this Note calls exclusive state powers), and impair the states' ability to structure integral operations in areas of traditional functions. ${ }^{61}$ Given that there are no longer any internal limits to national powers, the first requirement of this tripartite test would effectively immunize any national invasion of a substantive area from constitutional scrutiny. Should HodePs analysis be adhered to by the Court, the states would be vestigial organs, sovereigns in an empty realm.

Although the Tenth Amendment is the Constitution's only explicit gui-

56. Professor Stewart suggests that Type I power is more fundamental than Type II because it is "more basic and logically prior" to other types of power. Stewart, supra note 33, at 1232.

57. E.g., J. ELY, DEMOCRACY AND DISTRUST (1980).

58. National League of Cities v. Usery, 426 U.S. 833, 851 (1976) (quoting Coyle v. Oklahoma, 221 U.S. $559,580(1911)$ ).

59. 101 S.Ct. 2352 (1981).

60. 426 U.S. 833 (1979).

61. 101 S.Ct, at 2366. 
dance on the question of which substantive areas of social policy are left to the states, the content of these powers has been at least partially filled in by judicial decision, and it is clear that some such powers exist. In Erie Railroad v. Tomkins, ${ }^{62}$ the Court, in invalidating the then-longstanding, judicially created national common law, held that Congress has no power to make law in the substantive areas covered by that common law ${ }^{63}$ because the Constitution allocates that power to the states. ${ }^{64}$ While Erie teaches that the Constitution places some areas of substantive social policy

62. 304 U.S. 64 (1938).

63. Id. at 78. The court gave as examples commercial law and the law of torts. Id.

64. Id. at 80. The Erie decision was widely accepted, but some commentators have suggested that it should have rested on statutory, not constitutional grounds. See Clark, State Law in the Federal Courts: The Brooding Omnipresence of Erie v. Tompkins, 55 YALE L.J. 267, 278 (1946); Cook, The Federal Courts and the Conflict of Laws, 36 ILL. L. REV. 493, 515-24 (1942); Ely, The Irrepressible Myth of Erie, 87 HARV. L. REV. 693, 706 (1974). The Court, however, recognized the constitutional basis of the Erie doctrine in Bernhardt v. Polygraphic Co. of America, 350 U.S. 198, 202 (1956). Other commentators have agreed that the Erie doctrine is constitutional. See Friendly, In Praise of Erie-And of the New Federal Common Law, 39 N.Y.U. L. REV. 383, 385-98 (1964); Mishkin, Some Further Last Words on Erie-The Thread, 87 HARV. L. REV. 1682 (1974).

Professor Ely also argues against the proposition that Erie creates a sphere of state power that the national government may not enter. Ely, supra, at 705-06. Professor Mishkin agrees with him on this issue, while arguing that Erie is a constitutional decision in that it prohibits both Congress and the courts from exceeding the powers delegated to them by the Constitution. Mishkin, supra, at 1682-83. In the Ely-Mishkin view, there are apparently no exclusive state powers other than those powers not granted to Congress by Article I of the Constitution. The view is, of course, consistent with the Darby theory of the Tenth Amendment. United States v. Darby, 312 U.S. 100, 124 (1941); see note 43 supra.

This principle has been taken to be the meaning of the majority opinion in Hanna v. Plumer, 380 U.S. 460 (1965) (national courts will not be bound in diversity cases by state procedural rules when those rules conflict with valid national procedural rules). Justice Harlan's concurring opinion in Hanna argued that the majority was wrong to the extent that its reasoning would allow a national procedural rule to prevent the enforcement of a substantive state rule in diversity cases. $I d$. at 474-78 (Harlan, J., concurring). Harlan's view has received scholarly support. See McCoid, Hanna v. Plumer: The Erie Doctrine Changes Shape, 51 VA. L. REV. 884, 907-08 (1965); Stason, Choice of Law Within The Federal System: Erie versus Hanna, 52 CoRNELl L.Q. 377, 400-01 (1967). Because, absent any intrusion upon state substantive law, the federal procedural rule would be a valid exercise of national power, the Harlan view reduces to the proposition that there is a sphere of state law into which the national government may not enter even when it is given certain types of plenary power that would seem to enable it to do so. See Ely, supra, at 700-02. To the extent that Hanna suggested the contrary, it may be called into question by National League of Cities v. Usery, 426 U.S. 833. (1976), which held that "there are attributes of sovereignty attaching to every state government which may not be impaired by Congress, not because Congress may lack an affirmative grant of legislative authority to reach the matter, but because the Constitution prohibits it from exercising the authority in that manner." Id. at 845 . Of course, National League of Cities reached only the question of the national government's use of the commerce clause. Id. at 852 n.17.

In Walker v. Armco Steel Corp., 446 U.S. 740, 747-48 (1980), the Court applied the Hanna approach of examining whether the national procedural rule is "within a constitutional grant of power," id. at 748, without considering whether a state power had been invaded. Since the Court applied the state procedural rule under this analysis, the issue of a conflict between it and the national rule was not reached. Id. at 752 n.14.

Reading National League of Cities and Erie together leads to the conclusion that there are areas of substantive social policy over which states have exclusive power. Those like Professor Ely who criticize the "state enclave" theory of Erie (which is nothing more than a different name for the theory of exclusive state powers) do so because they fail to recognize the shift in Federalism analysis that this Note has examined. See pp. 1701-02 supra. 


\section{Conditional Grants}

exclusively within the province of the states, it does not identify those areas. ${ }^{65}$ They have, however, been spelled out in other contexts.

One such area is the power to establish laws of descent and succession. In United States v. Burnison, ${ }^{66}$ the Court held that the Constitution allocates to the states the power to make law regulating the succession of property. ${ }^{67}$ This power is so fundamental that national courts will generally not consider probate matters, even when there is diversity of citizenship. $^{68}$

A second area is the power to regulate family life. ${ }^{69}$ This area includes the power to set rules regulating such matters as marriage and divorce, ${ }^{70}$ adoption and foster parent relations, ${ }^{71}$ and the removal of children from their parents for neglect and abuse. ${ }^{72}$

65. The Court said only that "Congress has no power to declare substantive rules of common law applicable in a State whether they be local in their nature or 'general,' be they commercial law or a part of the law of torts." 304 U.S. at 78. Erie was decided before the full extent of the national government's power under the commerce clause was recognized.

66. 339 U.S. 87 (1950).

67. Id. at 91-92. Burnison was cited approvingly in United States v. Little Lake Misere Land Co., 412 U.S. 580, 592 n.10 (1973). The Court took the same position without citing Burnison in dicta in Labine v. Vincent, 401 U.S. 532, 583 (1971) (overruled on other grounds by Trimble v. Gordon, 430 U.S. 762 (1977)). The specific holding of Labine, that a state's estate law may discriminate against illegitimate children, has been overturned by Trimble v. Gordon, 430 U.S. 762 (1977). Trimble, however, does not call into question Labine's recognition that the Constitution assigns the power to make law on this subject to the states, see 430 U.S. at 776 n.17, as the Court seems to have recognized when it limited Trimble in Lalli v. Lalli, 439 U.S. 259, 268 (1978) (plurality opinion) (Powell, J.).

Labine, written by Justice Black, implicitly limited the scope of an earlier decision written by Black, United States v. Oregon, 366 U.S. 643 (1961) (constitutional for national statute to require that personal property left by wards of national government who die in national facilities be turned over to national government). Justices Douglas and Whittaker dissented in that case, arguing that the national law intruded upon state powers guaranteed by the Tenth Amendment. Id. at 654-55. Oregon can only be reconciled with Burnison and Labine by seeing the former as a case in which the national government was, in effect, charging the individual for the service he was receiving in accordance with his ability to pay, rather than as a case involving the law of estates.

In Zschernig v. Miller, 389 U.S. 429 (1968), the Court invalidated an Oregon succession statute addressing foreign heirs. The decision, while based on the fact that matters of foreign affairs are left to Congress, in no way suggests that exclusive state powers can be invaded by Congress. The decision can be reconciled with the claim that the law of succession is an exclusive state power because the Court interpreted the Orcgon law as an attempt not to regulate succession, but to make foreign policy. Id. at 437-38; see id. at 441 (state not permitted to "establish its own foreign policy").

68. P. BATOR, P. MISHKIN, D. ShAPIRO, \& H. WEChSLER, HART \& WECHSLER'S THE FEDERAL COURTS AND THE FEDERAL SYSTEM 1183-89 (2d ed. 1973); Hart, The Relations Between State and Federal Law, 54 COLUM. L. REV. 489, 509 (1954).

69. McCarty v. McCarty, 101 S.Ct. 2728, 2735 (1981); Sosna v. Iowa, 419 U.S. 393, 404 (1975) ("TThe] area [of domestic relations] has long been regarded as a virtually exclusive province of the States."); In re Burrus, 136 U.S. 586, 593-94 (1890).

70. Sosna v. Iowa, 419 U.S. 393, 404 (1975).

71. Cf. Caban v. Mohammed, 441 U.S. 380, 391 (1979) (state has strong interest in providing procedure for adoption of illegitimate children); Smith v. Organization of Foster Families for Equality \& Reform, 431 U.S 816, 856 (1977) (Stewart J., concurring in judgment) (foster parent-foster child relationship is "wholly a creation of the State").

72. See Stanley v. Illinois, 405 U.S. 645,649 (1972). 
A third area left to the states is the power to create land use laws ${ }^{73}$ and general property law. ${ }^{74}$ State power is so wide in the latter area that, in the context of the Fourteenth Amendment's property clause, under which one might expect "property" to be defined by the Constitution, the Supreme Court has made clear that the meaning of "property" is generally a matter of state law. ${ }^{75}$

73. See Village of Belle Terre v. Boraas, 416 U.S. 1, 4 (1974); Village of Euclid v. Ambler Realty Co., 272 U.S. 365, 387 (1926).

One limit on the extent of this power is national regulation pursuant to the property clause, U.S. CoNST. art. IV, $\S 3$, cl. 2, under which the national government may regulate nationally held lands or activities that affect them, Kleppe v. New Mexico, 426 U.S. 529, 536-41 (1976) (upholding under property clause national regulation of wild animals that roam on both public and private lands). While Kleppe contains language characterizing the national government's power under the clause as "without limitations," id. at 539, a careful reading of the case suggests that the Court is referring to internal limits. Kleppe does not necessarily mean that the national government has the power to regulate land use unrelated to nationally held preserves. See Sax, Helpless Giants: The National Parks and the Regulation of Private Lands, 75 Mich. L. REV. 239, 250-55 (1976); Note, The Property Power, Federalism, and the Equal Footing Doctrine, 80 COLUM. L. REV. 817, 825 (1980).

The Court assumed without deciding that the power to regulate land use is what this Note would call an exclusive state power in Hodel v. Virginia Surface Mining \& Reclamation Ass' n, 101 S. Ct. 2352, 2369 n.34 (1981). Due to the interpretation it gave National League of Cities v. Usery, however, see p. 1703 supra, it upheld a national intrusion on that power.

74. See Bishop v. Wood, 426 U.S. 341,349 n.14 (1976) (there is no "federal common law of property rights").

It is unclear what "general property law" means and what the extent of this state power is. The law of commercial instruments, for example, while sometimes referred to as a matter of "property law," is not within this power, because it is closely connected to commerce. The general rule is that "property ownership is not governed by a general federal law, but rather by the laws of the several States." Oregon ex rel. State Land Bd. v. Corvalis Sand \& Gravel Co., 429 U.S. 363, 378 (1977); see Davies Warehouse Co. v. Bowles, 321 U.S. 144, 155 (1944). When a national interest is directly implicated, however, national law is often applied under the doctrine of Clearfield Trust Co. v. United States, 318 U.S. 363 (1943). There are numerous property law cases in which national law has been applied under Clearfield Trust reasoning. See, e.g., McGarty v. McCarty, 101 S.Ct. 2728 (1981) (national law on military retirement pay preempts state community property law); United States v. Chandler, 410 U.S. 257, 262 (1973) (national rather than state law governs validity of donations of United States Savings Bonds); Free v. Bland, 369 U.S. 663, 668 (1962) (national law creating right of survivorship in United States Savings Bonds preempts state community property law); United States v. Shimer, 367 U.S. 374, 381 (1961) (national rather than state law applies to terms of national veterans' mortgage loan guarantees). These cases do not disprove the claim that there is an exclusive state power to make property law; they merely limit the extent of that power to situations not directly affecting a legitimate national interest. See Sunderland v. United States, 266 U.S: $226,232-33$ (1924).

The importance of the states' power here causes the Court often to assume, absent evidence to the contrary, that Congress intends to apply state law, even though it may have the power to apply national law. See, e.g., United States v. Yalzell, 382 U.S. 341, 352 (1966) (state law of coverture prevented Small Business Administration recovery of deficiency on SBA loan). While such an analysis is clearly appropriate for cases in which the national government has a legitimate interest and in which there is a question whether state law has been adopted by Congress or should be adopted by the courts, the Court often analyzes cases in which the state law must apply of its own force as if they involve the question of congressional adoption of state law. Such an approach may have the advantage of avoiding the unnecessary confrontation of constitutional issues, but is inappropriate when Congress does not have the power to preempt state law. See United States v. Little Lake Misere Land Co., 412 U.S. 580, 605 (1973) (Stewart, J., concurring in judgment); id. at 606-07 (Rehnquist, J., concurring in judgment). The analysis of this Note suggests that it would be more appropriate to approach such cases by examining whether the matter is one left to the states by the Constitution.

75. Leis v. Flynt, 439 U.S. 438, 441 (1979); Board of Regents v. Roth, 408 U.S. 564, 577 (1972). 
A fourth substantive area left to the states is the power to provide certain services, such as police and fire protection, to their citizens. In $\mathrm{Na}$ tional League of Gities v. Usery, ${ }^{76}$ the Court invalidated an amendment ${ }^{77}$ that applied the Fair Labor Standards $\mathrm{Act}^{78}$ to state and municipal employees, at least in part because that legislation adversely affected the ability of states to provide those services. ${ }^{79}$ If the provision of such traditional services were not an exclusive state power, the adverse effects on the states' ability to provide them would not have been a reason to overturn the amendment. ${ }^{80}$ Because the national government may not impair the exercise of an "attribute of sovereignty" even if it has constitutional authority that would otherwise enable it to reach a matter, ${ }^{81}$ those attributes of sovereignty must be exclusively state powers. ${ }^{82}$

It necessarily follows that a state's decision not to provide these services is as protected as its decision to provide them under a certain procedure. Were the national government to provide the services under the general welfare clause, ${ }^{83}$ it would be interfering with state decisions on how much of and what kinds of such services to provide; moreover, the interference would be more serious than that caused by the application of minimum wage laws to state employees. ${ }^{84}$

This doctrine does not rob the due process clause of meaning by allowing a state to declare that an entitlement is not property for purposes of the Fourteenth Amendment. Whether the state-created property right is to be protected by the due process clause is a matter of national constitutional law. Memphis Light, Gas \& Water Div. v. Craft, 436 U.S. 1, 9 (1978). The doctrine simply means that the Constitution does not determine whether the interest exists.

76. 426 U.S. 833 (1976).

77. The Fair Labor Standards Amendments of 1974, Pub. L. No. 93-259, § 6, 88 Stat. 55 (1974).

78. 29 U.S.C. §§ 201-219 (1976 \& Supp. III 1979).

79. The Court noted that application of minimum wage laws to states and municipalities increased the cost of providing services, forcing cutbacks in the provision of these services. It gave as an example that California had been forced to reduce training of highway patrolmen. 426 U.S. at 84647.

80. For this very reason National League of Cities did not overrule United States v. California, 297 U.S. 175 (1936). Because the latter case concerned only the regulation of a state-run railroad, and therefore did not involve an exclusive state power, see National League of Cities v. Usery, 426 U.S. $833,854 \mathrm{n.18}, 855$ (1976), the intrusion of national regulation on state activity did not violate the Constitution.

81. 426 U.S. at 845.

82. Professor Tribe recognized this interpretation of National League of Cities, but rejected it for the curious reason that the Court has not protected the states' role as "lawmaker[s] and regulator[s] of private conduct." Tribe, Unraveling National League of Cities: The New Federalism and Affrmative Rights to Essential Government Services, 90 HARV. L. REV. 1065, 1074-75 (1977). As this Note seeks to demonstrate, however, there are areas in which the states are indeed the exclusive regulators of private conduct.

83. "The Congress shall have Power . . to pay the Debts and provide for the common Defence and general Welfare of the United States .... "U.S. CONST. art. I, $\S 8, \mathrm{cl}$. 1 .

84. Thus the Court notes that one example of the exercise of a state's power to provide these services is the reliance on "volunteers." National League of Cities v. Usery, 426 U.S. 833, 850-51 (1976). The decision to rely on volunteers is essentially a decision to rely on private individuals to provide that service and not to provide it directly through a governmental unit. Thus a state's exclusive power must logically extend to that decision. Direct national provision of these services would impair that exercise of an exclusive state power, and would therefore be unconstitutional. See Stewart, 
The Court left unclear exactly which services fall within the realm of exclusive state power. Although the examples of "fire prevention, police protection, sanitation, public health, and parks and recreation" were given ${ }^{85}$ the Court explicitly indicated that the list was not all-inclusive. ${ }^{86}$ The Court also suggested including primary and secondary education and hospitals in the list. ${ }^{87}$ The responsibility for resolving which services fall within this exclusive state power rests, ultimately, with the courts. National League of Cities does indicate, however, that the determining factor is whether the service is an integral governmental function traditionally provided by the states. ${ }^{88}$

A fifth substantive power left to the states involves an intersection between Type I and Type II power. This power is the authority to use the coercive power of a state against its citizens. ${ }^{89}$ State powers to tax and to impose legal sanctions on individuals fall within this category. While the national government possesses a corresponding power, the state's power to exercise its own coercive authority is exclusively its own.90

Type III: Power to Take Part in Changing the Federal System. The Constitution gives the states a critical role in changing the federal system by making their participation a mandatory part of the amending process. ${ }^{91}$ State legislatures may, by petitioning Congress, begin the process of calling a constitutional convention. Furthermore, the states have the final say on the approval of any amendment, either through their legislatures or through conventions of their citizens. ${ }^{92}$ The provisions of the Constitution

supra note 33, at 1232 .

85. 426 U.S. at 851 .

86. Id. at 851 n.16.

87. Id. at 855 . Education has been recognized in other decisions as a matter of state power. As the Supreme Court noted in Brown v. Board of Educ., 347 U.S. 483, 493 (1954), "education is perhaps the most important function of state and local governments." More recently, the Court explicitly recognized the limitations on its own power to intervene in this field, pointing out that, "[b]y and large, public education in our Nation is committed to the control of state and local authorities." Epperson v. Arkansas, 393 U.S. 97, 104 (1968).

88. The Court seems to use the words "integral" and "traditional" interchangeably. Compare 426 U.S. at 851,855 ("integral governmental functions") with id. at 852 ("traditional governmental functions"). The test cannot be strictly historical because some services falling within the area have not been provided by the states throughout the country's history. For example, free public education did not become prevalent in the United States until about 1860. L. GREMIN, THE TRANSFORMIATION OF THE SCHOOL 13 (1961). The courts will undoubtedly consider both whether there is a tradition of state provision of the service and the importance of state provision of the service to the achievement of the goals of Federalism. Of course analysis of this sort is also required in applying National League of Cities to direct regulation of state governments.

89. See District of Columbia v. Train, 521 F.2d 971, 994 (D.C. Cir. 1975), vacated and remanded per curiam sub nom. EPA v. Brown, 431 U.S. 99 (1977) (national government may not force states to "administer and enforce federal regulatory programs").

90. The one exception to this power limits its extent without calling into question its existence. States must open their courts to the enforcement of rights created by national law if they open them to the enforcement of similar rights created by state law. Testa v. Katt, 330 U.S. 386, 394 (1947).

91. U.S. CONST. art. V.

92. Id. Historically there are two exceptions to this argument. First, the Fifteenth Amendment 
that require a state to agree before its representation in the Senate is reduced $^{93}$ or before another state is formed out of territory within its borders $^{94}$ further strengthen the states' role in the process of changing the federal system.

\section{The Limits on Exclusive State Powers}

To say that states possess exclusive powers is not to say that there are no limits on those powers. Virtually all of the provisions of the Bill of Rights have been applied to the states by incorporation in the Fourteenth Amendment. ${ }^{95}$ In addition, the Constitution establishes other limits to state power, both explicitly ${ }^{96}$ and by judicial interpretation. ${ }^{97}$ While state exercise of exclusive power is limited by judicial enforcement of individual rights, this limit presents no more threat to the exclusivity of these powers vis-a-vis the national government than such enforcement against the

was ratified by the states of Virginia, Mississippi, and Texas as a requirement of their readmission to the Union. Act of Apr. 10, 1869, ch. 17, § 6, 16 Stat. 40; J. MATHEWS, LEGISLATIVE AND JUDICIAL HISTORY OF THE FIFTEENTH AMENDMENT 75 (1909). Second, three of the states that, in theory, ratified the Fourteenth Amendment had previously rejected that amendment, and, along with other Southern States, subsequently had their governments replaced by Congress. See Coleman v. Miller, 307 U.S. 433, 448 (1939). Coercion was clearly an element in these ratifications. Powell, Changing Constitutional Phases, 19 B.U. L. REv. 509, 511 (1939). Both amendments have been accepted by the courts on the theory that the validity of an amendment is a political question. Coleman v. Miller, 307 U.S. at 449-50 (Fourteenth Amendment); White v. Hart, 80 U.S. (13 Wall.) 646, 649 (1872) (dictum) (Fourteenth and Fifteenth Amendments). It is doubtful that these incidents from the period immediately following the Civil War can serve as precedent for the proposition that, as a part of the normal amending process, Congress may force a state to pass an amendment. L. ORFIELD, THE AMIENDING OF THE FEDERAL CONSTITUTION 73-74 (1942).

A more serious question is whether the Court will address a case involving such an issue under the political question doctrine. Coleman holds only that the question of how to treat a legislature's previous rejection of, or recision of acceptance of, an amendment is a political question. 307 U.S. at 450 . Even if the entire matter is a political question, that fact does not release Congress from its duty to obey the Constitution, which clearly leaves the power of ratification to the states. Moreover, it is doubtful whether the political question doctrine would prevent a court from invalidating a law as clearly unconstitutional as one that interferes with a state's power to ratify a constitutional amendment. See Note, The Process of Constitutional Amendment, 79 CoLUM. L. REV. 106, 145-46 (1979) (Coleman's failure to disapprove of prior cases decided on merits and its quoting of one such case indicates that some amendment issues are justiciable even under Coleman).

93. U.S. CONST. art. V.

94. U.S. CONST. art. IV, $\S 3$, cl. 1.

95. E.g., Duncan v. Louisana, 391 U.S. 145 (1968) (right to trial by jury in criminal cases); Pointer v. Texas, 380 U.S. 400 (1965) (right to confront opposing witnesses at criminal trial); Malloy v. Hogan, 378 U.S. 1 (1964) (freedom from compelled self-incrimination); Gideon v. Wainwright, 372 U.S. 335 (1963) (right to counsel in felony cases); Mapp v. Ohio, 367 U.S. 643 (1961) (exclusion of evidence produced by illegal search or seizure). In applying the equal protection clause, however, the court has indicated that it will apply a more lenient test to the exercise of powers that this Note characterizes as exclusive state powers. Foley v. Connelie, 435 U.S. 291, 295-96 (1978) (exclusion of aliens from state police force upheld).

96. E.g., U.S. CONST. amend. XXIV (prohibiting poll tax in national elections); U.S. CoNST. amend. XXVI (establishing uniform 18-year-old voting age).

97. E.g., Roe v. Wade, 410 U.S. 113 (1973) (women's right to abortion); Griswold v. Connecticut, 381 U.S. 479 (1965) (right to use contraceptives); Pierce v. Society of Sisters, 268 U.S. 510 (1925) (right of parents to send children to private school). 
national government presents to the exclusivity of certain national powers vis-a-vis the states. Congressional regulation pursuant to the Fourteenth and Fifteenth Amendments and the guarantee clause, however, poses more difficult issues for the theory of exclusive state powers.

\section{The Fourteenth and Fifteenth Amendments}

Although legislation pursuant to section five of the Fourteenth Amendment $^{98}$ and section two of the Fifteenth Amendment, ${ }^{99}$ unlike legislation under the commerce clause, may invade what would otherwise be areas of exclusive state power, these national powers should not be understood to undermine the concept of such powers. The Fourteenth and Fifteenth Amendments were adopted to prevent the states from exercising their powers in ways that violate certain rights of individuals, particularly of blacks. ${ }^{100}$ Legislation pursuant to these post-Civil War amendments, unlike legislation pursuant to more general grants of power, may regulate the states' use of their exclusive powers because that is precisely the purpose of the post-Givil War amendments. ${ }^{101}$ In exercising this power, however, Congress is confined to the scope of the amendments. For example, while it may, when enforcing these amendments, order states to eliminate as qualifications for the right to vote literacy tests and other conditions that it finds prevent the exercise of constitutional rights, ${ }^{102}$ it may not use the amendments as instruments to force on the states voting rules not grounded in these amendments. ${ }^{103}$ The post-Civil War amendments do

98. "The Congress shall have power to enforce, by appropriate legislation, the provisions of this article." U.S. CONST. amend. XIV, \&5.

99. "The Congress shall have power to enforce this article by appropriate legislation." U.S. CONST. amend. XV, $\$ 2$.

100. The Slaughter-House Cases, 83 U.S. (16 Wall.) 36, 71-72 (1873).

101. City of Rome v. United States, 446 U.S. 156, 178-80 (1980); Fitzpatrick v. Bitzer, 427 U.S. 445, 453-56 (1976).

102. Katzenbach v. Morgan, 384 U.S. 641, 648-56 (1966); South Carolina v. Katzenbach, 383 U.S. 301, 333-34 (1966).

103. Oregon v. Mitchell, 400 U.S. 112, 129-30 (1970) (national requirement of 18-year-old vote in state elections overturned).

Justice Black's opinion in Mitchell helps resolve a possible ambiguity in Katzenbach v. Morgan, 384 U.S. 641 (1966), and South Carolina v. Katzenbach, 383 U.S. 301 (1966), on the scope of congressional power under section five of the Fourteenth Amendment and section two of the Fifteenth Amendment, respectively. In those two cases the congressional ban of literary tests had to be reconciled with the Court's decision in Lassiter v. Northampton County Bd. of Elections, 360 U.S. 45 (1959), which had held that literacy tests do not necessarily violate the Fourteenth or Fifteenth Amendments. In Morgan the state argued that Congress could not abolish a state's literacy test without a judicial finding that it violated the equal protection clause. The Court rejected this argument, ruling that Congress has the power to determine that literacy tests, as applied, violate the equal protection clause. 384 U.S. at 648-56. In South Carolina the state argued that literacy tests were constitutional under Lassiter, but the Court ruled that Congress could make a finding that the tests perpetuated discrimination and suspend them. 383 U.S. at 333-34.

Justice Black's was the swing vote in Mitchell, and four Justices either implicitly agreed with his explanation of Morgan and South Carolina, 400 U.S. at 293-96 (Stewart, J., concurring in part and 
not, therefore, provide a vehicle for wide-ranging invasions of exclusive state powers.

\section{The Guarantee Clause}

The guarantee clause of the Constitution ${ }^{104}$ has been suggested by at least one commentator as a possible basis for federal regulation of state governmental structure. ${ }^{105}$ The clause on its face authorizes only that Congress "guarantee . . a Republican Form of Government," not that Congress dictate the particulars of that form of government. In the many cases in which Congress has sought to interfere with state governmental structure, the guarantee clause has not been used as a basis for validating such intrusions. ${ }^{106}$ There being little basis in the text or the case law for the proposition that Congress may use the clause to invade exclusive state powers, it should be interpreted as serving only as a grant to the national government of the power to prevent states from adopting monarchial, dictatorial, or other non-republican forms of government. ${ }^{107}$

dissenting in part) (joined by Burger, C.J., and Blackmun, J.), or took an even stronger view, 400 U.S. at 205-09 (Harlan, J., concurring in part and dissenting in part). Justice Black's opinion makes clear that these conclusions do not mean that Congress can create constitutional requirements out of whole cloth, but only that Congress has broad power to enforce the provisions of the two amendments. 400 U.S. at 127-29. Congress, then, has the independent power to make determinations of fact, such as in Morgan and South Carolina, that literacy tests were discriminatory, and, on the basis of these factual determinations, to enact legislation to enforce the amendments. It may not, however, create new constitutional law, and thus Mitchell overturned the uniform 18-year-old voting age for state elections. For a criticism of Mitchell arguing for broader congressional power to interpret the Fourteenth Amendment, see Cohen, Congressional Power to Interpret Due Process and Equal Protection, 27 STAN. L. REV. 603 (1975).

The discussions of Mitchell, Morgan, and South Carolina in City of Rome v. United States, 446 U.S. 156, 173-78 (1980), and in Fullilove v. Klutznick, 448 U.S. 448, 476-77 (1980) (plurality opinion) (Burger, C.J.), while not completely clear on the issue, appear to follow Mitchelfs interpretation of the earlier cases. Justice Powell's opinion in Fullilove clearly limits the explanation of congressional power under the Fourteenth and Fifteenth Amendments in Morgan and South Carolina to enforcing, not creating, constitutional rights. Id. at 500-02 (Powell, J., concurring).

104. "The United States shall guarantee to every State in this Union a Republican Form of Government ...." U.S. CONST. art. IV, § 4.

105. W. WIECEK, THE GUARANTEE CLAUSE OF THE U.S. CONSTITUTION 300 (1972).

106. See, e.g., Oregon v. Mitchell, 400 U.S. 112 (1970) (invalidating requirement based on section five of the Fourteenth Amendment that states allow 18-year-olds to vote in state elections); Coyle v. Oklahoma, 221 U.S. 559 (1911) (invalidating requirement based on guarantee clause that state not move its capital for three years). It should also be noted that neither Katzenbach v. Morgan, 384 U.S. 641 (1966), nor South Carolina v. Katzenbach, 383 U.S. 301 (1966), relied upon the guarantee clause. Indeed, this broad view of the guarantee clause is inconsistent with the perceived need to adopt the Fourteenth, Fifteenth, Nineteenth, and Twenty-sixth Amendments.

107. That the framers felt a need to spell out this limited power may itself be indicative of the breadth of Type I exclusive state powers.

Because the guarantee clause has long been regarded as nonjusticiable, Baker v. Carr, 369 U.S. 186, 218-26 (1962); Luther v. Borden, 48 U.S. (7 How.) 1, 42-44 (1849), Congress, by using it, might attempt to avoid judicial invalidation of an act invading exclusive state powers. In Baker v. Carr the Court went so far as to say that challenges to congressional action on grounds of "inconsistency with" the clause are nonjusticiable. 369 U.S. at 224. The only cases in which Congress has sought to regulate the states directly provide little basis for this claim. In Coyle v. Oklahoma, 221 


\section{A Proposed Structure For Federalism}

The shift of Federalism analysis from an attempt to delineate the internal limits on national power to an attempt to give content to a zone of exclusive state powers, and the failure of coercion analysis to prevent states from allowing the national government to impinge on that zone through the use of conditional grants, suggest the need for a new doctrine to address transactions between the states and the national government. Since attempts to limit the national government's use of conditions have failed, the preservation of Federalism requires a doctrine that places limits on the states' power to agree to these conditions.

\section{A. The Requirement of Uninfluenced Decisionmaking}

Only a requirement that states make all decisions on matters falling within exclusive state powers free from the influence of national grants provides a workable standard for preserving the values of Federalism. Because the allocation of exclusive powers to the states indicates a constitutional intention that those powers not be exercised by the national government, a state's willingness to allow the national government to influence its decision on such matters by providing it with funds raises serious constitutional questions. ${ }^{108}$

The allocation of a matter exclusively to the states signifies a constitutional policy that the national government is not allowed to make the law in that area. That allocation reflects the goals that our Federalist system seeks to achieve: diffusion of power throughout the country, increased accountability of governmental institutions to the citizenry, promotion of efficiency and innovation, relief from the pressures of factionalism and regionalism, and diversity of both culture and politics. ${ }^{109}$ When a state voluntarily allows its decisions on matters within its exclusive powers to be influenced by a grant from the national government, it frustrates those

U.S. 559 (1911), the Court held that the congressional requirement that Oklahoma not move its capital was not a valid exercise of the guarantee clause. Id. at 567-68. In Georgia v. Stanton, 73 U.S. (6 Wall.) 50 (1868), the Court declared the destruction of state governments during Reconstruction a political question. Id. at 77 . The Court made no mention of the guarantee clause in spite of Georgia's attempt to rely on it. It is doubtful that a case arising out of the Civil War has any bearing on whether the Court may review a congressional attempt to use the clause to invade state powers. Furthermore, even assuming a challenge were nonjusticiable, nonjusticiability does not imply constitutionality. Congress has a duty to obey the Constitution independent of whether the Supreme Court may review its actions. Should the Court be unable to prevent congressional abuse of the guarantee clause, its inability to do so does not free Congress from its duty to obey the limits of the clause.

108. In the area of general police power-the area in which the national government may simply preempt state law-these questions do not arise. In this area, the states share their power with the national government, and hence uninfluenced decisionmaking is not constitutionally required. The present analysis applies only when exclusive state powers are at issue.

109. See pp. 1699-1700 supra. 


\section{Conditional Grants}

Federalist goals. While the Constitution does not explicitly require the states to exercise their exclusive powers so independently, it should be recognized that the Framers could not have foreseen the present financial dependence of the states on the national government. ${ }^{110} \mathrm{~A}$ requirement that states make decisions on matters within the realm of exclusive state power uninfluenced by national grants is necessary, therefore, to carry out the constitutional system of allocating power and to achieve the goals of Federalism. ${ }^{111}$

When tested against a standard of uninfluenced decisionmaking, state acceptance of grants whose conditions invade exclusive state powers fails. ${ }^{112}$ In practice, state legislatures often go beyond allowing national grants to influence their decisions on such policy matters. The states, in effect, cede the responsibility for making some decisions to the national government by accepting conditions that are subject to subsequent determination and revision by national agencies. ${ }^{113}$ This behavior constitutes an outright abdication of constitutional responsibility; it allows the national government not merely to influence policy, but to make it. Such an abdication is a dangerous threat to Federalism and should be found unconstitutional. Furthermore, many programs send funds directly to state agencies, with the state legislature never even participating in the process of assessing the program's or the condition's wisdom. ${ }^{14}$ It is not necessary,

110. See p. 1696 supra.

111. Of course this analysis does not call into question normal political influence over the development of policy on matters within the realm of exclusive state powers. Thus a President may threaten to oppose a Governor's reelection unless the Governor supports a particular policy within this realm.

112. There has been one judicial suggestion of the application to the states of a requirement like the one this Note proposes. In Carter v. Carter Coal Co., 298 U.S. 238 (1936), the Court indicated that state powers cannot be "abdicated." Id. at 295. The case did not involve conditional grants. The abdication language of Carter Coal was repeated by that opinion's author, Justice Sutherland, in his dissent in Steward Mach. Co. v. Davis, 30l U.S. 548, 615 (1937) (Sutherland, J., dissenting). The idea was not elaborated on and seems to have been forgotten.

This Note's argument is not undercut by language in cases that have held that a state's acceptance of conditions is not an abdication of its sovereignty. See, e.g., Carmichael v. Southern Coal \& Coke Co., 301 U.S. 495, 526 (1937) (absent coercion, state and national governments may engage in cooperative effort without unconstitutional surrender of sovereignty); Steward Mach. Co. v. Davis, 301 U.S. 548, 597-98 (1937) (states may accept conditions "if the essence of their statehood is maintained without impairment"). These cases do not distinguish between exclusive state powers and other state powers. Their failure to do so limits their force now that such a distinction is necessary.

113. For examples of programs whose conditions are subject to revision by national agencies, see p. 1715-16 infra (grants for community land use planning and for coastal land use planning).

114. See Brown, Federal Funds and National Supremacy: The Role of State Legislatures in Federal Grant Programs, 28 AM. U.L. REv. 279, 282-83 (1979). There has been a recent movement in state legislatures to channel national funds through the legislative appropriation process. Id. at 28384. The Supreme Court recently declined to hear a case upholding the right of the Pennsylvania legislature to do so. Thornburgh v. Casey, 440 U.S. 942 (1979), dismissing appeal from Shapp v. Sloan, $480 \mathrm{~Pa}$. 449, $391 \mathrm{~A} .2 \mathrm{~d} 595$ (1978). In other cases state supreme courts have ruled against these legislative efforts. E.g., MacManus v. Love, 179 Colo. 218, 499 P.2d 609 (1972); Opinion of the Justices to the Senate, 375 Mass. 851,378 N.E.2d 433 (1978). While this reform is a step in the right direction, it does not prevent legislatures from themselves accepting conditions subject to determination and revision by the national government. 
however, to examine whether the acceptance of a particular condition is a rational, calculated decision or an abdication of responsibility. In either case the state has failed to make an independent determination of the wisdom of the condition's underlying policies.

\section{B. General Application of the Requirement of Uninfuenced Decisionmaking}

A state's acceptance of a grant conditioned on a requirement that the state exercise one of its exclusive powers in a particular manner violates the requirement of uninfluenced decisionmaking. Of course, the states may still accept national grants. They may agree to comply with the most detailed set of conditions imaginable, as long as that grant and those conditions concern a program or function that does not fall within the realm of exclusive state power. The states may also accept conditions that require them to comply with national laws enforcing the post-Civil War Amendments, for those amendments were meant to allow Congress to regulate the states' exercise of their exclusive powers. ${ }^{115}$

Within the realm of exclusive state powers, a state may accept block grants-that is, grants with a condition that the funds go to a particular broad purpose, such as education-for such grants would not influence policy formulation on the matter. ${ }^{116}$ The acceptance of conditions requiring the adoption of a particular governmental structure, or the adoption of a particular policy within the realm of states' Type II exclusive power, would be unconstitutional. By contrast, a state's agreement to spend funds on managing its bureaucracy or on a broad matter within its Type II exclusive powers would be constitutional, for the state would make all specific policy decisions on how to spend the money.

The requirement of uninfluenced decisionmaking, unlike coercion analysis, is a limitation on state, not national, power. The state's acceptance of national conditions, not the conditions themselves, violates this doctrine. Challenges to the acceptance of conditions that invade exclusive state pow-

115. See pp. 1710 \& note 101 supra.

116. The popular technique of requiring states to match national funds would not meet the requirements of this doctrine. The acceptance of such funds would result in the state allowing the national government to influence the allocation of the state's budget between various possible programs that involve the exercise of exclusive state powers.

A state's acceptance of in-kind aid from the national government would also fail to meet this test if that aid is for matters falling within the realm of exclusive state powers. Such aid can be characterized as a monetary grant with the restrictive condition that it be spent for the purpose of purchasing a particular good. While acceptance of such a gift from an individual is not called into question by this analysis, when the gift comes from the national government it poses allocation of power problems. If the national government were to offer, for example, to "give" the states an entire school system, this "in-kind" aid would mask a dramatic shift of power from the states to the national government. 


\section{Conditional Grants}

ers must, therefore, come from parties other than the state, ${ }^{117}$ for the state is the party accused of acting unconstitutionally. The national government could obviously join as a party defendant in any such action, for it would have a stake in the outcome. The remedy in such a suit would be an injunction ordering the state not to accept the condition.

\section{Application to Particular National Grants}

There are numerous cases of conditions that impinge on exclusive state powers. State acceptance of these conditions violates the requirement of uninfluenced decisionmaking.

The Hatch Act ${ }^{118}$ impinges on the states' Type I power over the qualifications of state officials and employees ${ }^{119}$ by requiring that state government officials whose principal responsibility concerns an activity funded in part by national funds or loans not use their official influence or authority to affect an election or nomination, to run for office, or to solicit funds for a political organization. ${ }^{120}$ The conditioning of grants on acceptance of the Hatch Act has been upheld by the Supreme Gourt. ${ }^{121}$

Two national programs invade the states' Type II exclusive power over land use planning ${ }^{122}$ by funding the development of comprehensive community land use plans and the development and implementation of coastal zone use plans only when such plans meet national policy objectives. ${ }^{123}$ The Department of Housing and Urban Development recently tightened the regulations governing grants for community land use plans to ensure that state plans meet national land use goals. ${ }^{124} \mathrm{~A}$ state cannot receive national funds for the implementation of a coastal zone management plan until that plan meets national requirements and has been approved by the

117. Such parties would have to have the requisite personal stake in the action, in the form of a " 'distinct and palpable injury,'" Duke Power Co. v. Carolina Environmental Study Group, Inc., 438 U.S. 59, 72 (1978) (quoting Warth v. Seldin, 422 U.S. 490, 501 (1975)), and a "fairly traceable' causal connection between the claimed injury and the challenged conduct," id. (quoting Arlington Heights v. Metropolitan Hous. Dev. Corp., 429 U.S. 252, 261 (1977)). For an injured party, the second test should not be difficult to pass. Id. at 75 n.20 ("substantial likelihood" that the relief requested will redress the injury claimed" is all that is required).

118. 5 U.S.C. $\$ \S 1501-1508$ (1976 \& Supp. III 1979).

119. See pp. $1702-03$ supra.

120. 5 U.S.C. $\$ 1502$ (1976).

121. Oklahoma v. United States Civil Serv. Comm'n, 330 U.S. 127 (1947). As Justice Hans Linde has pointed out, the logic of Oklahoma allows Congress to prevent a state from having an elected Highway Commission, and would presumably allow any congressional regulation of the selection of officials administering programs aided by national funds. Linde, Justice Douglas on Freedom in the Welfare State, 39 WASH. L. REV. 4, 30 (1964).

122. See p. 1706 \& note 73 supra.

123. 40 U.S.C.A. $\S 461$ (West Supp. 1981) (community land use plans); 16 U.S.C.A. $§ ~ 1451-$ 1464 (West 1974 \& Supp. 1981) (coastal zone management).

124. 44 Fed. Reg. 54,432 (1979) (codified at 24 C.F.R. $\S 600.55$ ). The Department announced that activities that did not further national policy objectives would not receive future funding. 24 C.F.R. $§ 600.55$ (a) (1980). 
Secretary of Commerce. ${ }^{125}$

Conditions attached to national highway grants impinge on the states' Type II power to exercise their coercive force ${ }^{126}$ by requiring that states adopt and enforce a uniform maximum speed limit of fifty-five miles an hour. ${ }^{127}$ States must adopt laws or administrative regulations that punish those who violate this speed limit ${ }^{128}$ and must certify that they are enforcing those laws. ${ }^{129}$

All of the above conditions impinge on exclusive state powers. For that reason, state acceptance of them and the grants attached to them fails to meet the requirement of uninfluenced decisionmaking.

\section{Conclusion}

Applying a requirement of uninfluenced decisionmaking to the states would achieve the Federalist goals, implicit in our Constitution, that are inadequately protected by the present coercion analysis. Coercion analysis ignores the Federalism problems that occur when states voluntarily allow the national government to influence their policymaking, and is thus unworkable. If Federalism is to be taken seriously, the adoption of the doctrine of uninfluenced decisionmaking is necessary: no other doctrine provides a coherent explanation for preventing national intrusion into state realms while remaining consistent with the accepted post-1937 understanding of the extent of the national government's power. The shift of analysis from the limits of national power to the extent of exclusive state powers, brought about by the New Deal, makes this doctrine the most logical way of approaching the problems of Federalism implicit in conditional grants to state governments. Only a constitutional requirement of uninfluenced decisionmaking on matters of exclusive state power addresses the central issue involved: what limits should be placed upon the transfer of exclusive state powers by the states to the national government.

125. 16 U.S.C.A. $§ 1455$ (West 1974 \& Supp. 1981).

126. See p. 1708 supra.

127. 23 U.S.C. $\$ 154$ (1976 \& Supp. III 1979).

128. 45 Fed. Reg. 64491 (1980) (to be codified at 23 C.F.R. $\$$ 659).

129. 23 U.S.C. § 141 (Supp. III 1979); 45 Fed. Reg. 64491, 66492 (1980) (to be codified at 23 C.F.R. § 659.13). 